
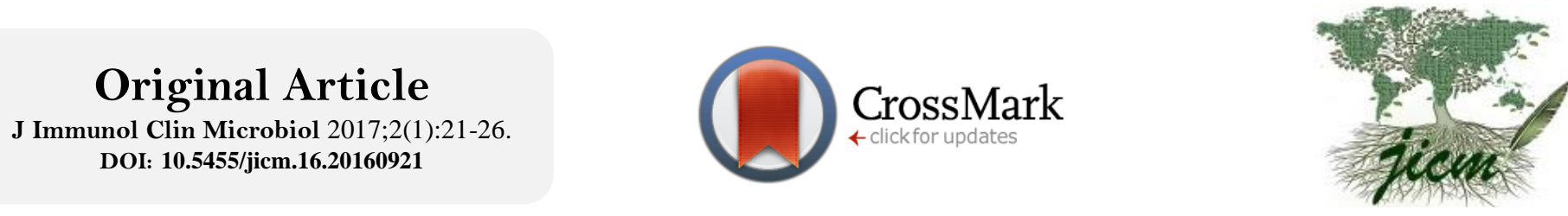

J Immunol Clin Microbiol

\title{
Evaluation of the epidemiological findings of acute rheumatic fever between 1981 and 2012
}

\author{
Özben Ceylan', Mahmut Keskin ${ }^{1}$, Mehmet Emre Ari ${ }^{1 *}$, Selmin Karademir ${ }^{1}$, \\ Utku Arman Örün ${ }^{1}$, Vehbi Doğan ${ }^{1}$, Senem Özgür ${ }^{1}$ \\ ${ }^{1}$ Department of Pediatric Cardiology, Dr. Sami Ulus Obstetrics and Gynecology, Children's Health and \\ Diseases Training and Research Hospital, Ankara, Turkey
}

\begin{abstract}
Background: The aim of this study was to determine the incidence of acute rheumatic fever (ARF) in Turkish children. Material and Methods: Our data was collected from the population and hospital based studies in Turkey between 1981 and 2012. We examined 12 studies reported from Turkey between these dates.

Results: Between 1981-1990, 1991-2000, 2001-2012; 573, 1677, 1688 patients had been followed up, respectively. In these three periods of follow up time carditis was observed in $(51,62$ and $71 \%$ of patients), arthritis in $(67,68,56 \%$ of patients), Sydenham's chorea in $(13,13$ and $13 \%$ of patients $)$ and erythema marginatum in $(2,0.1,1 \%$ of patients), respectively. Between 1981-1990, 1991-2000 and 2001-2012 the incidence of ARF was detected 1.1/100.000, $2.6 / 100.000$ and $2.3 / 100.000$, respectively.

Conclusion: While ARF incidence in Turkey had remained at a constant rate until 1980, a rapid decline occurred after this time, and this decline remained almost unchanged until 2012.
\end{abstract}

Key words: Acute rheumatic fever, Incidence, Prevalence, Turkey

\section{Introduction}

Acute rheumatic fever is a complication of group A $\beta$ hemolytic streptococcal pharyngitis (1). The disease usually occurs in children between 5-14 years of age (2). It can be prevented with early detection and adequate treatment of streptococcal pharyngitis. Rheumatic valvular lesions will also minimized when secondary prophylaxis applied regularly $(3,4)$. The diagnostic criteria for acute rheumatic fever was first described in 1944 by Jones, and it has been modified several times until 2015 (5-7). In 2015 the last modified criteria were accepted worldwide.
In developing countries, acute rheumatic fever is the leading cause of acquired heart disease in children and adolescents, while acute rheumatic fever incidence is declined in developed countries due to the improvement decline in the crowd live, improvement hygiene and nutrition and standards of living. After penicillin was introduced for treatment of pharyngitis, the incidence of acute rheumatic fever was decreased and even not observed in certain regions (8).
*Corresponding Author: Mehmet Emre Ar1, Department of Pediatric Cardiology, Dr. Sami Ulus Obstetrics and Gynecology, Children's Health and Diseases Training and Research Hospital, Ankara, Turkey E-mail: memreari@yahoo.com Received: Aug 12, 2016 Accepted: Sep 21, 2016 Published Online: Feb 15, 2017.
This is an Open Access article distributed under the terms of the Creative Commons Attribution Non-Commercial License (http://creativecommons.org/licenses/bync/4.0/) which permits unrestricted non-commercial use, distribution, and reproduction in any medium, provided the original work is properly cited. 
Approximately 300.000 new cases are arised in the world between 5-14 years old children every new year. The majority of cases are seen in developing countries, and the incidence is 200-300/100.000. It is difficult to determine the true incidence in these countries because of the insufficient data collection. The actual incidence of population-based surveillance studies reach up to $500 / 100.000(9,10)$.

Until now, there is not any nationwide study performed to detect the incidence and prevalence of acute rheumatic fever in Turkey, instead the studies were performed regionally $(11,12)$. The aim of this study is to determine the incidence of acute rheumatic fever throughout Turkey.

\section{Methods and materials}

In this report, data were obtained from the population and hospital based studies. All studies about acute rheumatic fever in Turkey were screened in "Ulakbim national database, Higher Education thesis database and PubMed" by entering words like "ARF, acute rheumatic fever, rheumatic fever, RF, rheumatic heart disease and RHD". In this study, we added the unpublished data from pediatric cardiology department of medical schools and also research hospitals in Turkey. We analyzed 12 studies reported from Turkey.

Because of the unreliable recordings, data before 1980 were excluded from the study. Data collections were analyzed by dividing the follow up period three decades, as 1981-1990, 1991-2000 and 2001-2012. Only the patients who had major diagnostic criteria of acute rheumatic fever arthritis, carditis, erythema marginatum, subcutaneous nodules and Sydenham's chorea; were included in this study. Other parameters such as minor criteria, supporting evidence, age and sex were excluded because of missing data and discrepancy among the centers. Patients with carditis were also classified according to valve involvement.

\section{Statistical analysis}

The statistical analysis was performed by SPSS (Statistical Package for the Social Sciences, Chicago, IL, version 16.0). Numeric variables are expressed as mean \pm $\mathrm{SD}$ and categorical ones are expressed as percentages $(\%)$.

\section{Results}

Between 1981-1990, 573 patients were detected. Among these patients carditis was detected in 294 (51\%), arthritis in $387(67 \%)$, Sydenham's chorea in $75(13 \%)$, erythema marginatum in 14 (2\%) respectively. Total 1677 patients were followed up between 1991 and 2000.

Table 1. The incidence of acute rheumatic fever reported from outside of Turkey.

\begin{tabular}{|c|c|c|c|c|}
\hline Researcher & Years & $\begin{array}{l}\text { Study } \\
\text { period } \\
\text { (years) }\end{array}$ & $\begin{array}{l}\text { Countr } \\
\mathbf{y}\end{array}$ & Incidence \\
\hline $\begin{array}{l}\text { Talbot et al. } \\
\text { (15) }\end{array}$ & $1978-1982$ & 4 & $\begin{array}{l}\text { New } \\
\text { Zealand }\end{array}$ & $\begin{array}{l}\text { Maori:88/10 } \\
0.000, \\
\text { Non- } \\
\text { Maori:9.3/10 } \\
0.000\end{array}$ \\
\hline $\begin{array}{l}\text { Veasy LG et } \\
\text { al. (16) }\end{array}$ & 1960-1964 & 14 & USA & $\begin{array}{l}4.7- \\
6.4 / 100.000\end{array}$ \\
\hline $\begin{array}{l}\text { Majeed HA } \\
\text { et al. (19) }\end{array}$ & 1984-1988 & 5 & Kuwait & $2.9 / 100.000$ \\
\hline $\begin{array}{l}\text { Eltohami EA } \\
\text { et al. (17) }\end{array}$ & 1988-1991 & 3 & India & $23 / 100.000$ \\
\hline $\begin{array}{l}\text { Omar A et } \\
\text { al. (20) }\end{array}$ & $1981-1990$ & 10 & Malaysia & $15.8 / 100.000$ \\
\hline $\begin{array}{l}\text { Steer AC et } \\
\text { al. (23) }\end{array}$ & $2005-2007$ & 3 & Fiji & $15.2 / 100.000$ \\
\hline $\begin{array}{l}\text { Vinker } S \text { et } \\
\text { al. (24) }\end{array}$ & 2000-2005 & 5 & Israel & $\begin{array}{l}0-30 \quad \text { years } \\
3.2 / 100,000 \\
-\quad 14 \\
\text { years:7.5:10 } \\
0,000\end{array}$ \\
\hline $\begin{array}{l}\text { Lawrence } \\
\text { JG et al. } \\
(25)\end{array}$ & $1997-2010$ & 13 & $\begin{array}{l}\text { Australi } \\
\mathrm{a}\end{array}$ & $\begin{array}{l}\text { Male:162/10 } \\
0.000, \\
\text { Female:228/ } \\
100.000\end{array}$ \\
\hline $\begin{array}{l}\text { Milne RJ et } \\
\text { al. (26) }\end{array}$ & 2000-2009 & 10 & $\begin{array}{l}\text { New } \\
\text { Zealand }\end{array}$ & $\begin{array}{l}\text { Maori:40.2/1 } \\
00.000, \\
\text { Non- } \\
\text { Maori/Pacifi } \\
\text { c:2.1/100.00 } \\
0, \quad \text { Pacific: } \\
81.2 / 100.000\end{array}$ \\
\hline $\begin{array}{l}\text { Pennock } \quad \text { V } \\
\text { et al. (27) }\end{array}$ & $2002-2011$ & 10 & $\begin{array}{l}\text { Region } \\
\text { of } \\
\text { Waikato } \\
\text { in New } \\
\text { Zealand }\end{array}$ & $\begin{array}{l}3.1 / 100,000- \\
\text { Maori: } \\
46.1 / 100,000\end{array}$ \\
\hline $\begin{array}{l}\text { Robin A et } \\
\text { al. (28) }\end{array}$ & $2002-2011$ & 10 & $\begin{array}{l}\text { Region } \\
\text { of } \\
\text { Northla } \\
\text { nd in } \\
\text { New } \\
\text { Zealand }\end{array}$ & $\begin{array}{l}\text { 7.7/100.000, } \\
\text { Maori:24.8/1 } \\
00.000, \\
\text { Non-Maori: } \\
0.6 / 100.000\end{array}$ \\
\hline
\end{tabular}

Among these patients carditis was detected in 1050 (62\%), arthritis in 1149 (68\%), Sydenham's chorea in 224 (13\%) and erythema marginatum was detected in 1 patient. There were 1688 patients between the years 2001 and 2012. Among these patients carditis were observed in $1212(71 \%)$, arthritis in 946 (56\%), Sydenham's chorea in $218(13 \%)$, erythema marginatum in 18 (1\%) (Figure 1 
and Table 3). Between 1981-1990, 1991-2000 and 20012012 the incidence of acute rheumatic fever was detected 1.1/100.000, 2.6/100.000 and 2.3/100.000, respectively (Figure 2).

Table 2. The incidence of acute rheumatic fever reported in Turkey.

\begin{tabular}{|c|c|c|c|c|c|c|}
\hline $\begin{array}{l}\text { Researcher } \\
\text { and Year }\end{array}$ & $\begin{array}{l}\begin{array}{l}\text { Study } \\
\text { period/range } \\
\text { (year) }\end{array} \\
\end{array}$ & Study place & $\begin{array}{l}\begin{array}{l}\text { Number of } \\
\text { cases } \\
\text { scanned }\end{array} \\
\end{array}$ & $\begin{array}{l}\text { Number } \\
\text { of patients }\end{array}$ & $\begin{array}{l}\text { ARF } \\
\text { Prevalence } \\
(\mathbf{1 / 1 0 0 . 0 0 0 )} \\
\end{array}$ & $\begin{array}{l}\text { ARF } \\
\text { Incidence } \\
(\mathbf{1} / \mathbf{1 0 0 . 0 0 0 )} \\
\end{array}$ \\
\hline $\begin{array}{l}\text { Gürson } \\
1966 \text { (30) }\end{array}$ & $1(1966)$ & İstanbul & 2500 & - & 700 & - \\
\hline $\begin{array}{l}\text { Yüksel } 1974 \\
\text { (32) }\end{array}$ & $1(1974)$ & İstanbul & & - & 165 & 277 \\
\hline $\begin{array}{l}\text { İmamoğlu } \\
1975 \text { (33) }\end{array}$ & $\begin{array}{l}10 \\
1985)\end{array}$ & Ankara & 3039 & - & $658 / 560$ & - \\
\hline $\begin{array}{l}\text { Öztürk } \\
1978 \text { (31) }\end{array}$ & $4(1974-1978)$ & Sivas/Denizli/ İstanbul & & - & $90 / 70 / 180$ & \\
\hline $\begin{array}{l}\text { Saraçlar } \\
1978(14)\end{array}$ & $5(1972-1976)$ & Ankara & 336705 & - & & $\begin{array}{l}18 / 21 / \\
16 / 17 \\
/ 20\end{array}$ \\
\hline $\begin{array}{l}\text { Parlar } 1980 \\
\text { (29) }\end{array}$ & $\begin{array}{l}20 \\
1979)\end{array}$ & Aegean region & - & 504 & - & - \\
\hline $\begin{array}{l}\text { Beyazova } \\
1987 \text { (13) }\end{array}$ & $\begin{array}{l}4 / 1 \quad(1970- \\
1973 / 1987)\end{array}$ & Ankara & & - & $56.6 / 36.7$ & - \\
\hline $\begin{array}{l}\text { Karaaslan } \\
1989(34)\end{array}$ & $2(1984-1985)$ & Diyarbakır & 40657 & 4065 & - & - \\
\hline $\begin{array}{l}\text { Yüksel } 1992 \\
\text { (32) }\end{array}$ & $2(1989-1990)$ & İstanbul & 7265 & - & $49 / 268$ & - \\
\hline $\begin{array}{l}\text { Olguntürk } \\
1995(11)\end{array}$ & $\begin{array}{ll}4 & \text { month } \\
(1995) & \end{array}$ & Ankara & 4086 & - & 73 & - \\
\hline $\begin{array}{l}\text { Örün } 2013 \\
\text { (12) }\end{array}$ & $\begin{array}{l}30 \quad(1980- \\
1989 / 1990- \\
1999 / 2000- \\
2009)\end{array}$ & Central Anatolia region & - & $\begin{array}{l}235 \\
498 \\
382\end{array}$ & - & $\begin{array}{l}37.6 \\
60.0 \\
21.0\end{array}$ \\
\hline
\end{tabular}

Table 3. Major components of acute rheumatic fever in Turkey between 1981-2012 years.

\begin{tabular}{lccc}
\hline & $\mathbf{1 9 8 1 - 1 9 9 0}$ & $\mathbf{1 9 9 1 - 2 0 0 0}$ & $\mathbf{2 0 0 1 - 2 0 1 2}$ \\
\hline $\begin{array}{l}\text { Number of } \\
\text { patients }\end{array}$ & 573 & 1677 & 1688 \\
$\begin{array}{l}\text { Carditis } \\
\text { Arthritis }\end{array}$ & $294(51 \%)$ & $1050(63 \%)$ & $1212(72 \%)$ \\
$\begin{array}{l}\text { Sydenham' } \\
\text { s chorea }\end{array}$ & $75(13 \%)$ & $224(13 \%)$ & $218(13 \%)$ \\
$\begin{array}{l}\text { Erythema } \\
\text { marginatu } \\
\text { m }\end{array}$ & $14(2 \%)$ & $16(1 \%)$ & $18(1 \%)$ \\
\hline
\end{tabular}

Figure 1. Major components of acute rheumatic fever in Turkey between 1965-2012 years.

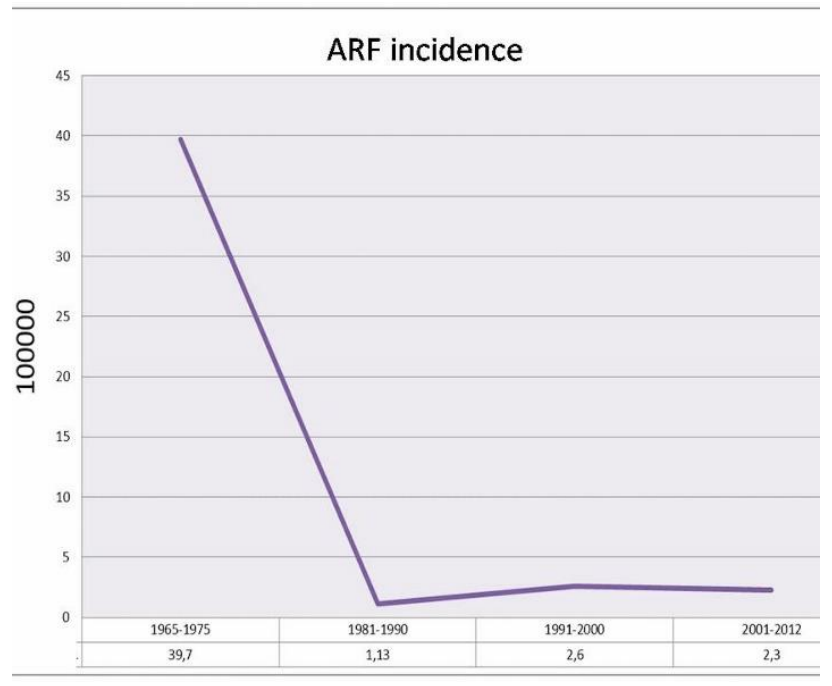


Figure 2. Incidence of acute rheumatic fever in Turkey between 1965-2012 years.

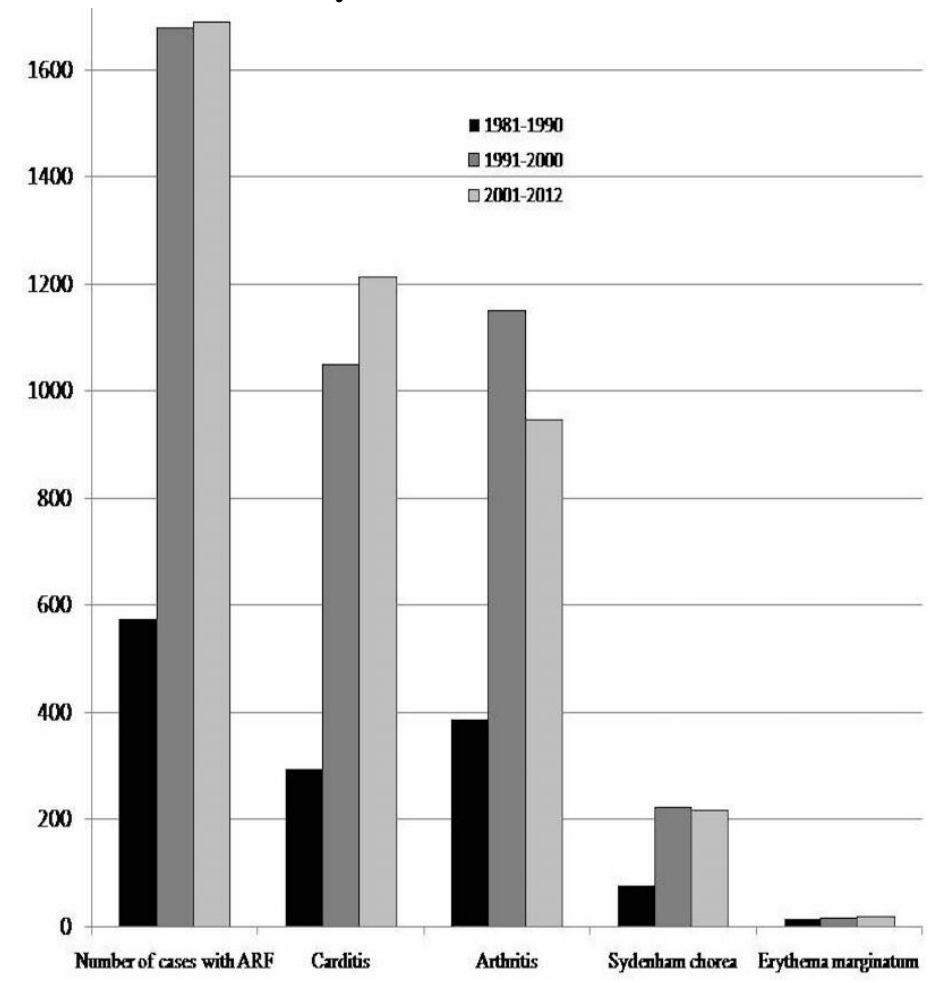

\section{Discussion}

According to Turkey Health Statistics Yearbook; in 1965, 1970 and 1975 the incidence of acute rheumatic fever was detected 36/100.000, 39/100.000 and 44/100.000, respectively. This study showed a dramatic decrease in the incidence of acute rheumatic fever when compared with the data of Health Statistics of Turkey prior to 1980. This dramatic decrease in the incidence is believed to be due to improvement of standards of living, nutrition and individual hygiene; widespread use of antibiotics, the increase in the number of pediatricians and pediatric cardiologists and also the awareness of the disease both among the physicians and the community.

Beyazova et al. (13) reported the incidence of acute rheumatic fever as 56.6/100.000 in Etimesgut, Ankara between 1970 and 1973. After 15 years they found the incidence as 36.7/100.000 in the same area. Similarly, Saraçlar et al. (14) found the incidence of acute rheumatic fever in the same area as 20/100.000 between 1972-1976. At the same time in New Zealand acute rheumatic fever incidence was found to be $88 / 100.000$ in Maoris and 9.3/100.000 in non-Maoris between the years 1978-1982 (15). The incidence of acute rheumatic fever was detected as 4.7-6.4/100.000 in the state of Utah between 1960-1964 (16). Incidence of acute rheumatic fever was determined as 36/100.000 in 1965, 39/100.000 in 1970, 44/100.000 in 1975 according to data obtained from Turkish Health Statistics Yearbook. In the studies performed before 1980s in our country, the incidence of acute rheumatic fever remained approximately at the same level (Table 1, 2).

Between 1980-1990 mostly prevalence studies were performed in Turkey. Örün et al. (12) reported the incidence of acute rheumatic fever as 37.6/100.000 between the years 1980-1989 in a local study from central Anatolia region. In this period, the incidence of acute rheumatic fever was found to be as low as $1.1 / 100.000$ as in Turkey. In the same period the incidence of acute rheumatic fever in different parts of the world were reported to be 51/100.000 in Malaysia between 1981-1990, in India 51/100.000 between 19881991, in Kuwait 23/100.000 between 1984-1988 and in Qatar 15.8/100.000 between 1984-1994, respectively (1720). In our study, a marked decrease in the incidence of acute rheumatic fever was detected when compared with the data of Turkey Statistics of Health before 1980. This decrease can be due to social and cultural development of our country, economic development summit and corresponds to more globalized era.

We found the incidence of acute rheumatic fever 2.6/100.000 throughout Turkey between 1990-2000. In the same period, Örün et al. (12) reported the incidence of acute rheumatic fever was as 60/100.000 in central Anatolia region. In a local study in Ankara, Karademir et al. (21) detected the incidence of acute rheumatic fever as 107.7/100.000 between the years 1990-1992. According to our information, among this period of time both in Turkey and throughout the world prevalence studies were dominated the literature; we could not find studies based on the incidence of acute rheumatic fever except the two studies mentioned above. When compared with the previous decade we observed that the incidence of acute rheumatic fever was doubled. The possible causes of this increase is due to the increase correct diagnosis of acute rheumatic fever rather than the increase in the number of the patients.

Between 2001-2012 years the incidence of acute rheumatic fever was detected as 2.3/100.000 throughout Turkey. In the same period, Örün et al. (12) found the incidence of acute rheumatic fever as 21/100.000 in 
Central Anatolia region. Narin et al. (22) reported the incidence as 7.4/100.000 between the years 1998-2011 in Kayseri.

In the same period the incidence of acute rheumatic fever in different parts of the world was reported as in Fiji 15.2/100.000 between 2005-2007. Two study were reported from Israel between the years 2000-2005, incidence of acute rheumatic fever was detected as $3.2 / 100.000$ between 0-30 years of age, and in the other study including the patients between the years of age 514 the incidence was reported to be as 7.5/100.000 (23, 24).

The incidence of acute rheumatic fever was not changed when compared with the previous decade.

Acute rheumatic fever incidence can be as high as 50/100.000. The highest incidence has been reported in Australia and New Zealand $(19,25)$. Örün et al. (12) reported the incidence of acute rheumatic fever as 21/100.000 in Central Anatolia region between 20002009 in Turkey. The incidence of acute rheumatic fever was quite low as 2.3/100.000 during this period in Turkey. At the same time in the north of Australia acute rheumatic fever incidence was reported as 162/100.000 in males and 228/100.000 in females between 5-14 age (26). In New Zealand, between the years 2000-2009, and among children whose age was between 5 and 14 years, the incidence of acute rheumatic fever was found in Maori, non-Maori/Pacific, Pacific and all children $40.2 / 100.000, \quad 2.1 / 100.000, \quad 81.2 / 100.000$ and $17.2 / 100.000$, respectively. In the same study acute rheumatic fever incidence between the years 2000-2009 compared with 1993-2009 years, in 1993-2009 years acute rheumatic fever incidence was found in Maori and Pacific increased $79 \%$ and $73 \%$, respectively, but in nonMaori/Pacific decreased $71 \%$ (25). Similarly, in New Zealand acute rheumatic fever incidence was found to be $3.1 / 100.000$ and 46.1/100.000 in the region of Waikato and in the Maori population between the years 20022011 , respectively. In the same period in the region of Northland the incidence of acute rheumatic fever in the whole population, in the population of Maori and in nonMaori population were found to be 7.7/100.000, $24.8 / 100.000,0.6 / 100.000$, respectively (26-28). The incidence of acute rheumatic fever was very low when compared to Maori population of New Zealand where it is almost the same with non-Māori / Pacific population.
We detected that the frequency of the major findings of acute rheumatic fever; arthritis, Sydenham's chorea and erythema marginatum did not change during the last three decades but the frequency of carditis was increased. This increased frequency may be attributed to the increased number of pediatric cardiologists and widespread use of echocardiography all over the country so that silent carditis were also be diagnosed.

\section{Limitations}

Most of our data were collected from the Central Anatolia and the Marmara regions of Turkey. Because the number of pediatric cardiology centers is relatively low in Black Sea and East regions of Turkey this study may not reflect the exact incidence in our country.

\section{Conclusion}

As a result, the incidence of acute rheumatic fever was more or less had a constant speed until 1980 in Turkey while there has been a rapid decline after the 1980s and this declined speed has remained unchanged at a fixed rate until 2012. We determined that the rate of the incidence of acute rheumatic fever in Turkey was similar to the rates observed in developed countries. The rapid decline in the incidence of acute rheumatic fever in Turkey may be attributed due to the improvement of individual hygiene, nutrition and standards of living, the decrease in the population, widespread use of antibiotics, the increased number of pediatricians and pediatric cardiology departments and the awareness of the disease both among physicians and public. We believe that the incidence of ARF might increase again, since in 2015 the newly defined diagnostic criteria of ARF facilitates the diagnosis of ARF in countries where the incidence of ARF is high.

Ethics Committee Approval: N.A.

Informed Consent: N.A.

Peer-review: Externally peer-reviewed.

Conflict of Interest: No conflict of interest was declared by the author.

Financial Disclosure: The author declared that this study has received no financial support.

\section{References}

1. Carapetis JR, Steer AC, Mulholland EK, Weber M. The global burden of group A streptococcal diseases. Lancet Infect Dis 2005;5: 685-94. 
2. Parnaby M, Carapetis JR. Rheumatic fever in indigenous Australian children. J Paediatr Child Health 2010; 46: 527533.

3. Carapetis JR, Currie BJ. Clinical epidemiology of rheumatic fever and heart disease in tropical Australia. Adv Exp Med Biol 1997; 418: 233-236.

4. Feinstein AR, Stern EK, Spagnuolo M. The prognosis of acute rheumatic fever. Am Heart J 1964; 68: 817-834.

5. Ferrieri P. Proceedings of the Jones Criteria Workshop. Circulation 2002; 106: 2521-2523.

6. Jones TD. Diagnosis of rheumatic fever. JAMA 1944; 126: 481-484.

7. Gewitz MH, Baltimore RS, Tani LY, Sable CE, Shulman ST, Carapetis J, et al. Revision of the Jones criteria for the diagnosis of the rheumatic fever in the era of Doppler echocardiography: A scientific statement of the American Heart Association. Circulation 2015; 131: 1806-1818.

8. Gordis L. The virtual disappearance of rheumatic fever in the United States: lessons in the rise and fall of disease. T. Duckett Jones memorial lecture. Circulation 1985; 72: 11551162.

9. Carapetis JR, Currie BJ, Mathews JD. Cumulative incidence of rheumatic fever in an endemic region: A guide to the susceptibility of the population? Epidemiol Infect 2000; 124: 239-44.

10. Carapetis JR, McDonald M, Wilson NJ. Acute rheumatic fever. Lancet 2005; 366:155-168.

11. Olguntürk R, Canter B, Tunaoglu FS, Kula S. Review of 609 patients with rheumatic fever in terms of revised and updated Jones criteria. Int J Cardiol 2006;112: 91-98.

12. Örün UA, Ceylan O, Bilici M, Karademir S, Ocal B, Senocak F, et al. Acute rheumatic fever in the Central Anatolia Region of Turkey: a 30-year experience in a single center. Eur J Pediatrics 2012;171: 361-368.

13. Beyazova U, Benli D, Beyazova M. Akut romatizmal ateş görülme sıklığı. Turkish Journal of Pediatric Disease 1987; 2: 76-80.

14. Saraçlar M, Ertuğrul A, Özme Ş. Akut romatizmal ateş insidansı ve romatizmal kalp hastalıkları prevalansı. Türk Kardiyoloji Derneği Arşivi 1978; 7: 50-54.

15. Talbot RG. Rheumatic fever and rheumatic heart disease in the Hamilton health district: I. An epidemiological survey. $N Z$ Med $J$ 1984; 97: 630-634.

16. Veasy LG, Wiedmeier SE, Orsmond GS, Ruttenberg HD, Boucek MM, Roth SJ, et al. Resurgence of acute rheumatic fever in the inter mountain area of the United States. $N$ Engl $J$ Med 1987; 316: 421-427.

17. Eltohami EA, Hajar HA, Folger GM Jr. Acute rheumatic fever in an Arabian Gulf country- effect of climate, advantageous socioeconomic conditions, and access to medical care. Angiology. 1997; 48: 481-489.

18. Grover A, Dhawan A, Iyengar SD, Anand IS, Wahi PL, Ganguly NK. Epidemiology of rheumatic fever and rheumatic heart disease in a rural community in northern India. Bull World Health Organ 1993; 71: 59-66.

19. Majeed HA, Doudin K, Lubani M, Shaltout A, Doussary L, Suliman MA. Acute rheumatic fever in Kuwait: the declining incidence. Ann Saudi Med 1993; 13: 56-59.

20. Omar A. Pattern of acute rheumatic fever in a local teaching hospital. Med J Malaysia 1995; 50:125-130.
21. Karademir S, Demirçeken F, Atalay S, Demircin G, Sipahi $\mathrm{T}$, Teziç T. Acute rheumatic fever in children in the Ankara area in 1990-1992 and comparison with a previous study in 1980-1989. Acta Paediatr 1994; 83: 862-865.

22. Narin N, Mutlu F, Argun M, Ozyurt A, Pamukcu O, Baykan A, et al. Incidence and clinical features of acute rheumatic fever in Kayseri, Central Anatolia, 1998-2011. Cardiol Young 2015; 25: 745-751.

23. Steer AC, Kado J, Jenney AW, Batzloff M, Waqatakirewa L, Mulholland EK, et al. Acute rheumatic fever and rheumatic heart disease in Fiji: prospective surveillance, 2005- 2007. Med J Aust 2009; 190: 133-135.

24. Vinker S, Zohar E, Hoffman R, Elhayany A. İncidence and clinical manifestations of rheumatic fever: a 6 year communitybased survey. Isr Med Assoc J 2010; 12: 78-81.

25. Lawrence JG, Carapetis JR, Griffiths K, Edwards K, Condon JR. Acute rheumatic fever and rheumatic heart disease: incidence and progression in the Northern Territory of Australia, 1997 to 2010. Circulation 2013; 128: 492-501.

26. Milne RJ, Lennon DR, Stewart JM, Vander Hoorn S, Scuffham PA. Incidence of acute rheumatic fever in New Zealand children and youth. J Paediatr Child Health 2012;48: 685-691.

27. Pennock V, Bell A, Moxon TA, Reed P, Maxwell F, Lennon D. Retrospective epidemiology of acute rheumatic fever: a 10-year review in the Waikato District Health Board area of New Zealand. N Z Med J 2014; 127: 26-37.

28. Robin A, Mills C, Tuck R, Lennon D. The epidemiology of acute rheumatic fever in Northland, 2002-2011. N Z Med J 2013; 126: 46-52.

29. Parlar A, İnan DÖ. Çocuklarda akut romatizmal ateş. Ege Üniversitesi Tip Fakültesi Dergisi 1980; 3: 19.

30. Gürson CT, Neyzi O. İstanbul'un Rami gece kondu bölgesinde çocuk sağlığı konusunda araştırmalar. Kağıt ve Basım işleri Anonim Şirketi, İstanbul, 1966.

31. Öztürk M, Öztürk E. Sivasta ilk ve orta öğrenim öğrencilerinde kalp hastalıkları prevalansı. Türk Kardiyoloji Derneği Arşivi 1978; 7: 71.

32. Yüksel H, Akıncı T, Yaldıran A, Özdemir H,Öztürk E, Öztürk M, Demiroğlu C. İstanbul İli Kırsal Kesiminde Romatizmal Kalp Hastalığı Prevalansı. Türk Kardiyoloji Derneği Arşivi 1992; 20: 10-13.

33. İmamoğlu A. Ankara'da ilkokul çocuklarında romatizmal kalp hastalıkları sıklı̆ı̆ı. Ankara Üniversitesi Tlp Fakültesi Degisi 1975; 28: 3-4.

34. Karaaslan S, Oran B, Reisli I, Erkul I. Acute rheumatic fever in Konya, Turkey. Pediatr Int 2000; 42: 71-75.

How to cite?

Ceylan O, Keskin M, Arı ME, Karademir S, Örün A, Doğan V, Özgür S. Evaluation of the epidemiological findings of acute rheumatic fever between 1981 and 2012. J Immunol Clin Microbiol 2017; 2(1):21-26. DOI: http://dx.doi.org/10.5455/jicm.16.20160921

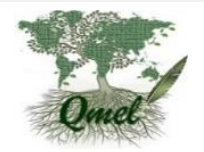

Published by The QMEL.org

International Medical Education Library 